\title{
O novo paradigma demográfico
}

Os aproximados 190 milhões de habitantes residentes no Brasil, contados pelo Censo Demográfico de 2010, são resultados de uma História populacional iniciada há mais de 100 anos.

As migrações internacionais foram responsáveis pela sua miscigenação e crescimento acentuado na virada do século XIX. A redução da mortalidade infantil, iniciada no final da Segunda Guerra Mundial, aliada à alta fecundidade gerou um crescimento populacional elevado no período 1950-1970 e uma população muito jovem. Esse período, conhecido como baby boom, foi marcado pelo temor de uma explosão demográfica.

O baby boom foi mais curto que o esperado; durou apenas duas décadas. A partir dos anos 1970, a fecundidade iniciou um processo de queda acelerada e sustentada, acompanhada pela continuação da redução da mortalidade que hoje beneficia mais a população em idade avançada. Esses dois processos ocorreram em curto período de tempo e, simultaneamente, em quase todos os países em desenvolvimento.

Desde o começo deste século, a fecundidade das mulheres brasileiras está abaixo da taxa que garante a reposição da população. Atualmente, a taxa de fecundidade total está em torno de 1,7 filho por mulher. Nos anos 1950 foi de 6,1. Hoje, um brasileiro vive em média 73,5 anos, 43 a mais que no início do século passado. Sumarizando, nasce menos gente e vive-se mais.

Já se notam duas consequências desse processo: contração da população e superenvelhecimento. $O$ Brasil não é mais um país de jovens. É provável que o Censo de 2030 encontre o número máximo de brasileiros que se pode vislumbrar, cerca de 208 milhões, dos quais $20 \%$ serão idosos. A partir daí, mantidas as mesmas tendências, esse contingente começará a diminuir e o formato da pirâmide etária se inverterá. Os baby boomers estão envelhecendo e se transformando nos elderly boomers. A preocupação com o "excesso" de crianças está dando lugar para o "excesso" de idosos.

Outras mudanças importantes ocorreram no período: aumento da escolaridade da população e da participação da mulher no mercado de trabalho, redução nos diferenciais por gênero na vida privada e social, mudanças nos arranjos familiares, especialmente na nupcialidade, menor duração das uniões conjugais, mudanças nos contratos tradicionais de gênero, redução no número de cuidadores familiares e um novo perfil epidemiológico.

O envelhecimento populacional está acontecendo antes de o Estado brasileiro resolver as necessidades sociais básicas, como educação e saúde, e entrou na agenda das políticas públicas, a partir de uma visão negativa do processo. No entanto, esta visão foi responsável pela legitimação de alguns direitos sociais como a universalização da aposentadoria, filas especiais, assentos reservados nos transportes públicos, gratuidade nos transportes urbanos, meia entrada e outros.

Apesar disso, várias questões não estão resolvidas e podem se agravar em um futuro próximo. Enquanto se pode ter certeza sobre um crescimento acelerado da população idosa nos próximos 30 anos, não se sabe sobre como sobreviverão os longevos em termos de saúde, autonomia e renda. Essas são condições importantes para a dependência ou não de qualquer grupo populacional.

Espera-se que a mortalidade continue a se reduzir e a vida a se alongar, mas reconhece-se que é difícil projetar o limite desse alongamento. A redução da oferta de força de trabalho implicará em uma diminuição no número de contribuintes para a seguridade social, o que leva a se perguntar se será possível para o Brasil continuar mantendo a dissociação entre envelhecimento e pobreza. O cuidado do idoso frágil é também uma questão não resolvida. Essa responsabilidade continua sendo atribuída à família sem considerar as mudanças que nela ocorrem.

Sumarizando, o que se sabe é que se está diante de um fato novo na História: envelhecimento e redução da população. Portanto, diante de novos desafios.

Ana Amélia Camarano

Instituto de Políticas Econômicas Aplicadas (IPEA) 


\section{The new demographic paradigm}

The approximately 190 million inhabitants living in Brazil counted by the 2010 Demographic Census are the outcome of a population expansion that began more than 100 years ago.

The international migrations were responsible for the miscegenation and rapid growth of the population at the turn of the nineteenth century. The reduction of infant mortality, which began at the end of World War II, coupled with high fertility generated rapid population growth in the 1950-1970 period and a very young population. This period, known as the baby boom was marked by the fear of a demographic explosion.

The baby boom was shorter than expected and only lasted two decades. From the 1970s onwards, fertility entered a period of rapid and sustained decline, accompanied by the continuation of the reduction in mortality which today benefits the elderly population more. These two processes occurred over a short period of time and simultaneously in almost all the developing countries.

Since the beginning of this century, the fertility of Brazilian women is below the rate that ensures population replacement. Currently, the total fertility rate is around 1.7 children per woman. In the 1950s it was 6.1. Today, Brazilians live on average 73.5 years, 43 more than at the beginning of the last century. In essence, fewer people are born, though they live longer.

Two consequences of this process are already apparent: population contraction and super aging. Brazil is no longer a country of young people. It is likely that the 2030 Census will find that the maximum number of Brazilians that can be envisioned will be about 208 million, of which $20 \%$ will be elderly. From then onwards, if the same trends prevail, this contingent will begin to decrease and the format of the age pyramid will be inverted. The baby boomers are aging and becoming elderly boomers. The concern with the "excess" of children is giving way to the "excess" of the elderly.

Other major changes occurred during the period: increased education of the population and the participation of women in the labor market, reduction in gender differentials in private and social life, changes in family arrangements, especially in marriage rates, shorter duration of marriages, changes in traditional gender contracts, reduction in the number of family caregivers and a new epidemiological profile.

Population aging is occurring before the Brazilian State sorts out basic social needs such as education and health and it is the public policy agenda, based on a negative view of the process. However, this view has been responsible for the legitimation of some social rights such as universal retirement, special queues, seats reserved in public transport, gratuity in urban transport, half price admission, among others.

Despite this, several issues remain unresolved and may become more accentuated in the near future. While one can be certain about a rapid growth of the elderly population over the next 30 years, it is not known how the long-lived will survive in terms of health, autonomy and income. These are important conditions for the dependence or otherwise of any population group.

It is expected that mortality will continue to decline and people will live longer, but it is acknowledged that it is difficult to project the limits of life expectancy The reduction in the supply of labor will result in a decrease in the number of contributors to social security, which leads one to wonder if it will be possible for Brazil to continue to maintain the dissociation between aging and poverty. The care of the frail elderly individual is also an unresolved issue. That responsibility continues to be attributed to the family without considering the changes that occur in it.

In short, what we know is that we are facing a new fact in history: aging and a shrinking population. Thus, new challenges are ahead.

Ana Amélia Camarano

Instituto de Políticas Econômicas Aplicadas (IPEA) 
